\title{
シクロテトラシランおよびシクロテトラゲルマンの アゾベンゼン存在下での光反応
}

(1989 年 10 月 28 日受理)

\author{
榊原章人・円谷 健・加部義夫・安藤 亘 $^{*}$
}

環状芳香族シランの光化学に関しては，三員環化合物の化学以外はほとんど報告がなく，その反応性 およびへテロ原子を含む化合物との反応に大変興味が持たれる。本研究は, オクタフェニルシクロテト ラシランおよびシクロテトラゲルマンの光機能性物質としての可能性を検討することを目的とし, ケイ 素ーケイ素結合およびゲルマニウムーゲルマニウム結合との強い相互作用が期待されるアゾ化合物存在下 での光反応を検討した。

オクタフェニルシクロテトラシランとアゾベンゼンおよび $4,4^{\prime}$-ジメチルアゾベンゼンの光反応にお いては, 1-(1,2-diarylhydrazo)-1, 2, 2, 3, 3, 4, 4-heptaphenyl-1, 2, 3, 4-tetrasila-1, 2, 3, 4-tetrahydronaphthalene [1]，[2] を良好な収率で与えた。また，オクタフェニルシクロテトラゲルマンとア ゾベンゼンとの反応に拈いては，ゲルマニウムーゲルマニウム結合へアゾ基が導入したような，1，2， 3,4,4,5, 5, 6,6-decaphenyl-1,2-diaza-3,4,5,6-tetragermacyclohexane [3]が得られた。これらの 反応に拈ける反応中間体として, 現在のところシクロテトラシラン拉よびシクロテトラゲルマンとアゾ 化合物の光励起錯体の生成を考㝋ている。

\section{1 緒言}

ヶイ素ーケイ素結合を主鎖とするポリシラン類は，最近特に機 能性材料としての観点から注目を集めており，これまでその合 成および物理化学的性質など関して盛んに研究がなされてき だ。なかです，その光化学的挙動に関してはかなり多くの研究 がなされており，シリルラジカルやシリレンの生成がその主な初 期反応として知られている(1)（図式 1)。特に，環状芳香族シラン の光化学反応は，シリレンの生成を主反応とする三員環化合物の 化学がよく知られているが，他の環状シランの反応性およびへテ
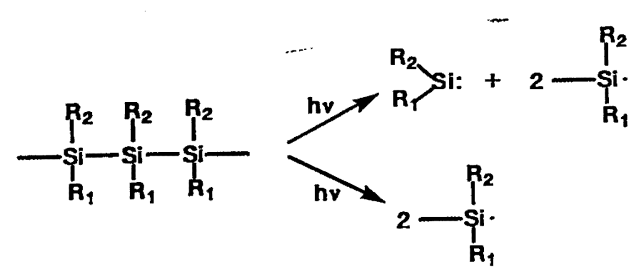

Scheme 1

筑波大学化学系, 305 つくば市天王台

1) a) R. West, J. Organomet. Chem., 300, 327(1986).

b) H. Watanabe, Y. Akutsu, A. Shinohara, S. Shinohara, Y. Yamaguchi, A. Ohta, M. Onozuka, Y. Nagai, Chem. Lett., 1988, 1883.

c) K. Sakamoto, K. Obata, H. Hirata, M. Nakajima, H. Sakurai, J. Am. Chem, Soc., 111, 7641(1989).
口原子を含む化合物との反応は非常に少なく，その光化学は大変 興味が持たれる。

著者らはこれまで, 三員環ケイ素化合物およびゲルマニウム化 合物を合成し，その大きなひずみエネルギーによる開環反応を検 討した結果, 酸素, 硫黄などのへテロ原子を含む新規な環状ケイ 素, ゲルマニウム化合物の合成に成功した ${ }^{23)}$ (図式 2)。

本研究は, シクロテトラシランおよびシクロテトラゲルマンの 光機能性物質としての可能性を榆討することを目的とし，ケイ 素ーケイ素およびゲルマニウムーゲルマニウム結合との強い相互作 用が期待されるアゾ化合物の存在での光反応を検討した。その結

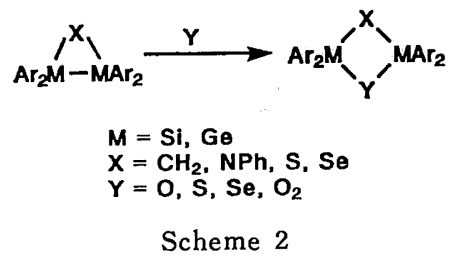

2) a) W. Ando, M.Kako, T. Akasaka, S. Nagase, T. Kawai, Y. Nagai, T.Sato, Tetrahedron Lett., in press.

b) W. Ando, T. Tsumuraya, Organometallics, 7, 1882(1988).

c) T. Tsumuraya, S. Sato, W. Ando, Organometallics, 7, 2015(1988).

3) S. Masamune, S. Murakami, H. Tobita, J. Am. Chem. Soc., 105, 7776(1983). 
果, アゾベンゼンによるシクロテトラシランの光転位拈よびシク ロテトラゲルマン環ヘアゾ基が導入する興味深い反応が見いださ れた。特にアゾベンゼン存在下で, ケイ素化合物とゲルマニウム 化合物がそれぞれ異なった光機能性を持つ大変興味潹い結果を得 たので, ここに報告する。

\section{2 結果と考察}

\section{1 シクロテトラシランとアソ化合物の光反応}

オクタフェニルシクロテトラシランとアゾベンゼンおよび $4,4^{\prime}-$ ジメチルアゾベンゼンの高圧水銀灯による光反応は，高収率で 1-(1, 2-diarylhydrazo)-1, 2, 2, 3, 3, 4, 4-heptaphenyl-1, 2, 3, 4tetrasila-1,2,3,4-tetrahydronaphthalene [1]，〔2]を与兄た (図式 3)。[1]，〔2]の ${ }^{13} \mathrm{C}-\mathrm{NMR}$ はそれぞれ大変複雑であり, 非等価なフェニル基を有している（図 1,2 )。これらの化合物の構
造決定はX線結晶解析により確認した（図 3)。〔2]のケイ素ーケ イ素およびヶイ素-炭素間結合距離と結合角は, 表 1 亿示すよう に通常の值を示す。 4 個のケイ素と 2 個の 0 -フェニレンの炭素 原子は一つの平面を形成し，また 10 個のフェニル基はそれぞれ 立体反発が最も小さくなるよらに互いに適当な二面角をなしてい る。

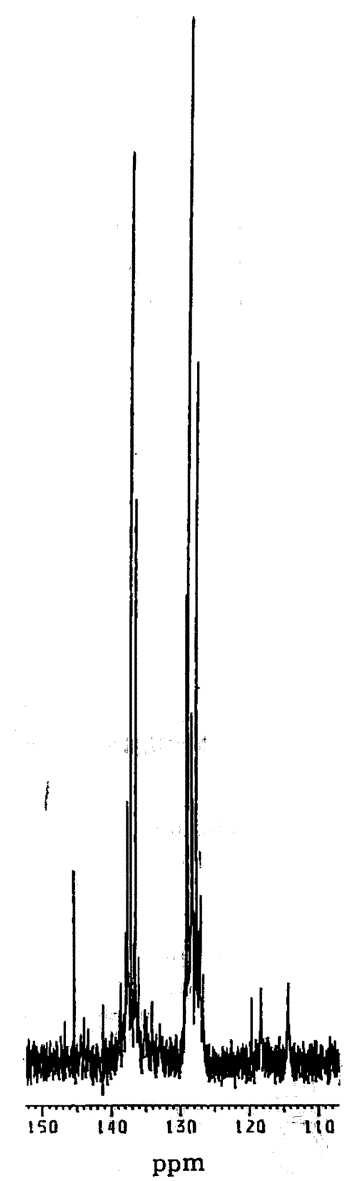

Fig. $2{ }^{13} \mathrm{C}-\mathrm{NMR}$ spectrum for [2]

Fig. $1{ }^{13} \mathrm{C}-\mathrm{NMR}$ spectrum for [1]

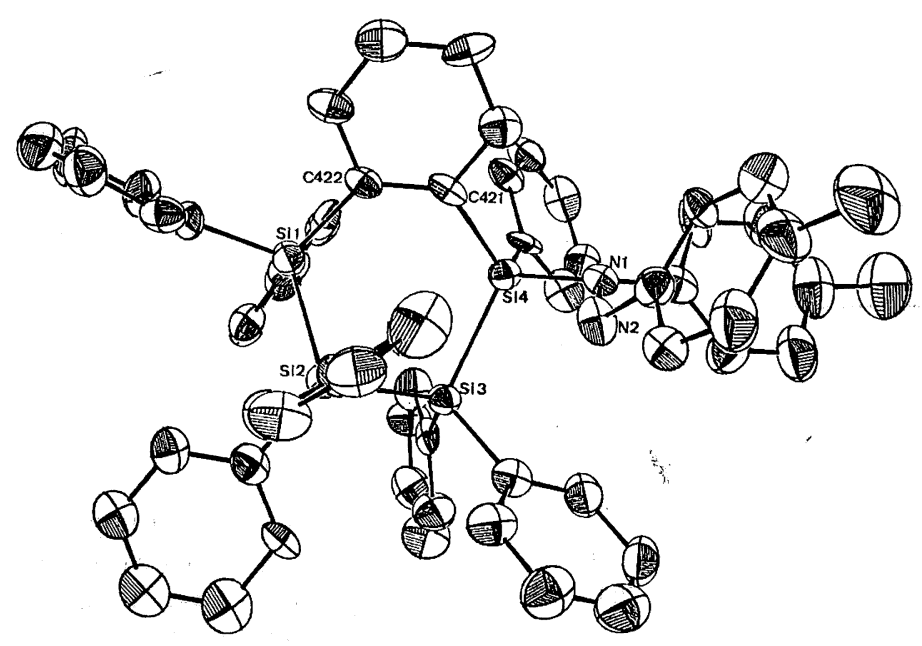

Fig. 3 An ORTEP diagram of [2] 
〔1],〔2〕の生成は, 困式4に示したようにビラジカル中間体 （I）または（II）を経て進行していると考えられる。（I）の生成 はアゾ化合物とシクロテトラシランの光励起錯体を経由し（II） の生成は, シクロテトラシランのケイ素-ケイ素結合の直接の光 解離で生成しているものと考えている。（I）または（II）から生

Table 1 Selected bond distances $(\AA)$ and angles $\left({ }^{\circ}\right)$ of $[2]$

Bond distances

Bond angles

\begin{tabular}{|c|c|c|c|}
\hline Si $1-\operatorname{Si} 2$ & $2.340(7)$ & Si $1-S i 2-S i 3$ & 100.5 \\
\hline $\mathrm{Si} 2-\mathrm{Si} 3$ & $2.385(6)$ & Si 2-Si 3-Si 4 & $104.1(2)$ \\
\hline Si $3-S i 4$ & $2.389(7)$ & 421 & $115.7(6)$ \\
\hline Si 1-C 422 & 1. $89(2)$ & C $422-\mathrm{Si} 1-\mathrm{Si} 2$ & $107.4(6)$ \\
\hline Si 4-C 421 & $1.91(2)$ & Si $3-\mathrm{Si} 4-\mathrm{N} 1$ & $108.4(5)$ \\
\hline Si $4-N 1$ & 1. $78(1)$ & C $421-\mathrm{Si} 4-\mathrm{N} 1$ & $106.8(6)$ \\
\hline N 1-N 2 & 1. $42(2)$ & Si $4-\mathrm{N} 1-\mathrm{N} 2$ & $110.3(8$ \\
\hline
\end{tabular}

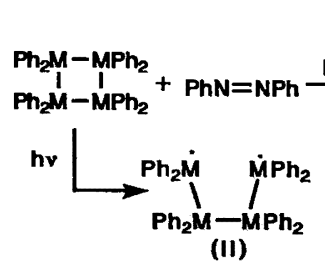

M=Si,Ge

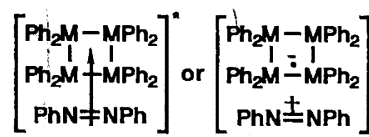

Scheme 4

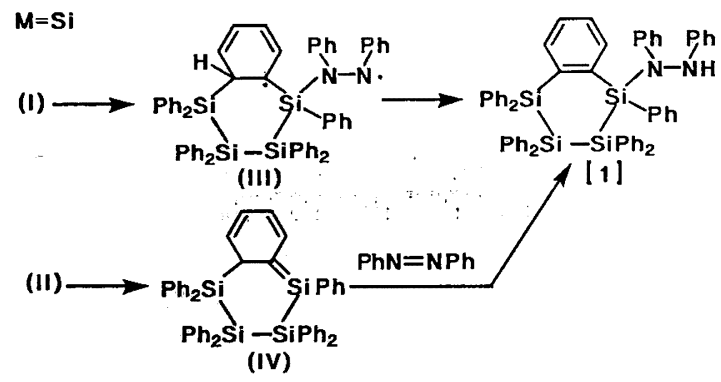

Scheme 5
成物への反応は図式 5 に示すよらに（I）からは、シリルラジカ ルのフェニル基への分子内付加扣よび水素の 1,5 転位を経て生 成するか，または(II) から石川らによってすでに明らかにされ ているように4)，シリルラジカルのフェニル基への転位を経てシ レン（N）を生成し，（N）とアゾ化合物のエン反応により生成 する機構が考えられる。アゾ化合物およびオクタフェニルシクロ テトラシランは, いずれも $300 \mathrm{~nm}$ 以上の領域に吸収を持ら、こ の反応条件下ではどちらの分子が直接光励起されているのか完全 に区別することは難しい。

アゾ化合物としてオルト位传置換基を有する $2,2^{\prime}, 6,6^{\prime}$-テトラ メチルアゾベンゼンとオクタフェニルシクロテトラシランの光反 応を検討した。この反応は大変複雑であり期待した生成物は得ら れなかった。オクタイソプロピルシクロテトラシランとアゾベン ゼンの光反応では，反応はまったく進行しなかった。オルト位に 置換基を有するアゾベンゼンおよびかさ高いイソプロピル基を有 するシクロテトラシラン系で反応が進みにくい事実は，おそらく シクロテトラシランの直接のケイ素ーケイ素結合の開裂よりむ, アゾ化合物とシクロテトラシランの励起錯体の生成を経る可能性 が高いことを示唆しているよらに思われる。

\section{2 シクロテトラゲルマンとアソベンゼンの光反応}

シクロテドラゲルマンはシクロテトラシランと同様な反応が期 待される。オクタ.フェニルシクロテトラゲルマンとアゾベンゼン の高王水銀灯での光反応は, $1,2,3,3,4,4,5,5,6,6$-デカフェニ ル-1, 2-ジアザ-3, 4, 5, 6-テトラゲルマシクロヘキサン〔3]を与 えた（図式 6)。この生成物は[1]，〔2〕と比較して非常に対称 性がよい ${ }^{13} \mathrm{C}-\mathrm{NMR}$ を示し（図 4), NH の IR 吸収が観測され なかったこと，さらに FAB-MASS スペクトル（罒 5,6）から，

〔3]のような構造であると同定した。

[1]，〔2]の化合物に拈いては，10 個のフェニル基が非等価 になるのに対し，〔3]は窒素-窒素結合の中心を通り六員環平面 と平行な $\mathrm{C}_{2}$ 対称軸をもち全部で五つの非等価なフェニル基が存

$\left(\mathrm{GePh}_{2}\right)_{4}+\mathrm{PhN}=\mathrm{NPh}$

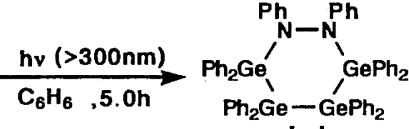

[3]
Scheme 6

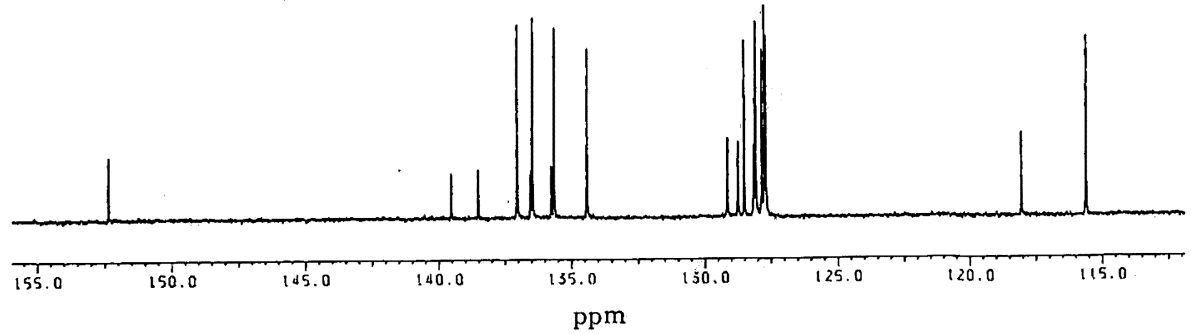

Fig. $4{ }^{13} \mathrm{C}-\mathrm{NMR}$ spectrum for [3]

4) a) M. Ishikawa, T. Fuchikami, T. Sugaya, M. Kumada, J. Am. Chem. Soc., 97, 5923(1975).

b) H. Sakurai, J. Organomet. Chem., 200, 261 (1980).
4） c ）大下浄治, 大崎裕司, 石川満夫, 日本化学会第 58 春 季年会, 1 II A 08(1989).

d) J. Ohshita, H. Ohsaki, M. Ishikawa, 36 th Symposium on Organometallic Chemistry, Japan, PA 103, (1989). 


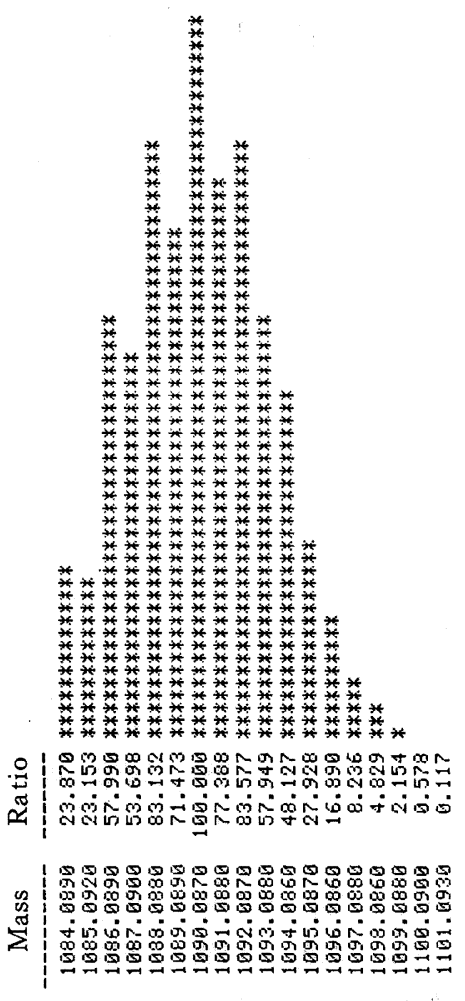

Fig. 5 Theoretical ion distribution of [3]

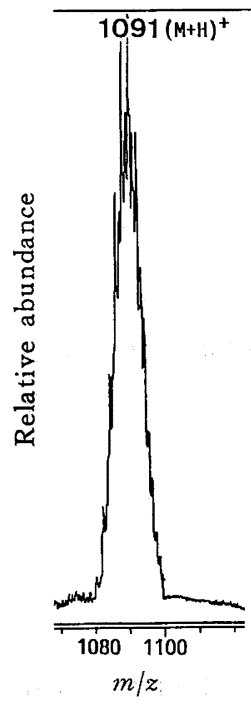

Fig. 6 Mass spectrum of [3]

在する。

〔3〕の生成は, アゾベンゼンとシクロテトラゲルマンの光励 起錯体を経て，中間体[I］から直接生成したものと考えた方が， 活性なビラジカル中間体 [II] とアゾベンゼンの 2 分子反応より も妥当と考えられる。

\section{3 結 論}

シクロテトラシランとシクロテトラゲルマンがそれぞれ異なっ た付加生成物を与えたことは，中間に生成するシリルラジカルお
よびゲルミルラジカルの反応性の差に由来するものと考える。 また，小員環ケイ素，ゲルマニウム化合物とへテロ原子を含む 化合物の光反応は, 新しい含へテロ原子ケイ素, ゲルマニウム化 合物の合成に有効な方法といえる。

\section{3 実 験}

\section{1 装 置}

核磁気共鳴スペクトル：JNM-PMX 60 SI, JNM-FX-90 Q (日本電子)；AM 500 (Bruker), MASS : PMV 6 MG（日立製作 所), IR : 260-50 (日立製作所), UV : JASCO Ubest-50 (日本分 光), 高速液体クロマトグラフィー: LC-08 型（日本分析工業） を用いた。融点は未補正である。

\section{2 試 料}

アゾベンゼンは和光純薬工業から購入し，へキサンから再結晶 して使用した。2，2'，6，6'-テトラメチルアゾベンゼン5)，オクタフ エニルシクロテトラシランタ), オクタイソプロピルシクロテトラ シラン7)，オクタフェニルシクロテトラゲルマンタ)は, 既報の方法 にしたがい合成を行った。また，4,4'-ジメチルアゾベンゼンは， $2,2^{\prime}, 6,6^{\prime}$-テトラメチルアゾベンゼンの合成法と同様の方法によ り合成を行った。

3.3 光反応

シクロテトラシランおよびシクロテトラゲルマンとアゾベンゼ ンの光反応

パイレックスガラス製やの反応管に，シクロテトラシランおよ

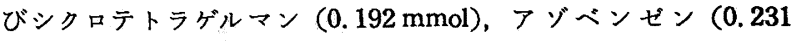
$\mathrm{mmol})$, 溶媒として水素化カルシウムから蒸留したベンゼン (15 $\mathrm{ml}$ ) を入れ, 真空ラインにより脱気操作を 4 回くり返した後, 反 応系内をアルゴンにより置換し，かきまぜながら水冷下高圧水銀 灯 (Riken, $400 \mathrm{~W}$ ) 照射を 3.5 時間から 5.5 時間行った。シ クロテトラシランのベンゼンに対する溶解性はあまりよくない。 反応後, 溶媒を留去し, 生成物を直接高速液体クロマトグラフィ 一により分離した。 生成物 [1]無色綿状結晶 収率 $75 \% \mathrm{mp} 190 \sim 192^{\circ} \mathrm{C}$ 。 ${ }^{1} \mathrm{H}-\mathrm{NMR}\left(\mathrm{CDCl}_{3}, \delta\right): 5.11(\mathrm{br}, \mathrm{s}, 1 \mathrm{H}), 6.10 \sim 7.70(\mathrm{~m}$, $49 \mathrm{H}$ )

${ }^{2} \mathrm{Si}-\mathrm{NMR}\left(\mathrm{CDCl}_{3}, \delta\right):-12.17,-24.86,-44.80,-48.15$ $\operatorname{MASS}(m / z): 910\left(\mathrm{M}^{+}\right)$

$\operatorname{IR}\left(\mathrm{CCl}_{4}, \mathrm{~cm}^{-1}\right): 3300(\mathrm{NH})$

$\mathrm{UV}($ Hexane $): \lambda_{\max }(\mathrm{nm}): 248$

元素分析

分析值 C $78.60 \%, \mathrm{H} 5.49 \%$ N $3.11 \%$

計算值 C $79.07 \%, \mathrm{H} 5.53 \% ， \mathrm{~N} 3.07 \%$

生成物〔2〕無色結晶 収率 $49 \% \mathrm{mp} 212 \sim 213^{\circ} \mathrm{C}$ 。

5) V. R. Holland, B. C. Saunders, F. L. Rose, A. L. Walpole, Tetrahedron, 30, 3299(1974).

6). a) H. Gilman, D. J. Peterson, A.W. P. Jarvie, H. J. S. Winkler, J. Am. Chem. Soc., 82, 2076(1960).

b) A.W.P. Jarvie, H. J.S. Winkler, D. J. Peterson, H. Gilman, ibid., 83, 1921(1961).

7) H. Watanabe, T. Muraoka, M. Kageyama, Y. Nagai, J. Organomet. Chem., 216, C 45(1981).

8) W. Ando, T. Tsumuraya, J. Chem. Soc., Chem. Commun., 1987, 1514. 
${ }^{1} \mathrm{H}-\mathrm{NMR}\left(\mathrm{CDCl}_{3}, \delta\right): 2.10(\mathrm{br}, \mathrm{s}, 6 \mathrm{H}), 5.05(\mathrm{br}, \mathrm{s}$, $1 \mathrm{H}), 6.07 \sim 7.47(\mathrm{~m}, 47 \mathrm{H})$

$\operatorname{MASS}(m / z): 938\left(\mathrm{M}^{+}\right)$

$\operatorname{IR}\left(\mathrm{CCl}_{4}, \mathrm{~cm}^{-1}\right): 3300(\mathrm{NH})$

$\mathrm{UV}\left(\mathrm{CH}_{2} \mathrm{Cl}_{2}\right): \lambda_{\max }(\mathrm{nm}): 251$

生成物 [3] 無色結晶 収率 $35 \% \mathrm{mp} 254 \sim 257^{\circ} \mathrm{C}$ 。

${ }^{1} \mathrm{H}-\mathrm{NMR}\left(\mathrm{CDCl}_{3}, \delta\right): 6.62 \sim 7.45(\mathrm{~m}, 50 \mathrm{H})$

${ }^{13} \mathrm{C}-\mathrm{NMR}\left(\mathrm{CDCl}_{3}, \delta\right): 115.57$ (d), 118.02 (d), 127.67

(d), 127.73 (d), 127.82 (d), 128.05 (d), 128.13 (d),

128.49 (d), 128.74 (d), 129.13 (d), 134.39 (d), 135.62

(d), 135.73 ( s), 136.43 (d), 136.52 ( s), 137.02 (d),

138. $49(\mathrm{~s}), 139.50(\mathrm{~s}), 152.33(\mathrm{~s})$

$\operatorname{FAB}-\operatorname{MASS}(m / z): 1091(\mathrm{M}+\mathrm{H})^{+}$

\section{$3.4 \mathrm{X}$ 線結晶解析 $\left.{ }^{9}\right)$}

〔2〕の結晶はへキサンを取り込むことが NMR スペクトルか ら確認されたのでメタノールにより再結晶を行った。得られた結 晶は切断することなく用い，毛管に不活性ガス下封入し，ENR AF-NONIUS CAD 4 四軸自動X線回折装置によって測定した。 結晶学データおよび測定条件のいくつかを表 2 に示す。グラフっ イトモノクロメーターで単色化した $M o K_{\alpha}$ 線を用い, $\omega-2 \theta$ 走 查法により走査速度 $1 \sim 7^{\circ} / \mathrm{min}(\omega)$ で測定し, 独立な 9593 個 の反射の内, $I \geq 3 \sigma(I)$ の 2139 個を用いて計算を行った。測定 強度は Lorentz 因子および偏光因子については補正したが吸収 については補正しなかった。

9）詳しいX線結晶解析のデータ（座標, 温度因子, 結合距離, 結合角, $F_{0}-F_{\mathrm{c}}$ 表）は日本化学会誌編集部に保存されて いる. (No. 15)
Table 2 Crystallographic data and some experimental conditions

Chemical formula

Crystal system

Space group

$a(l / \AA)$

$b(l / \AA)$

$c(l / \AA)$

$\beta\left(\phi / /^{\circ}\right)$

$U\left(V / \AA^{3}\right)$

$Z$

$D_{\mathrm{x}}\left(d / \mu \mathrm{g} \cdot \mathrm{m}^{-3}\right)$

$\mu\left(\mathrm{MoK}_{\alpha}\right)\left(n / \mathrm{mm}^{-1}\right)$

Number of reflections

Reflections used for the

calculations

Measured range $\left(2 \theta \%^{\circ}\right)$

Size of crystal used $\left(V / \mathrm{mm}^{-3}\right)$

Scan width

Scanned method

$R$

$R_{\mathrm{w}}$

$\mathrm{C}_{62} \mathrm{H}_{54} \mathrm{~N}_{2} \mathrm{Si}_{4}$
Monoclinic
$\mathrm{P} 21 / \mathrm{c}$
$11.151(4)$
$20.033(7)$
$23.540(6)$
$101.11(2)$
5160.1
4
1.21
1.5
9593
2139
$1 \sim 50$
$0.2 \times 0.2 \times 0.4$
$0.8+0.35 \tan \theta$
$\omega-2 \theta$
0.084
0.097

解析は直接法によって行った。水素を除く 68 個の原子の内, 59 個の原子は直ちに求まり, その他の炭素原子は D-合成により 求めた。また，水素原子以外のすべての原子の位置および温度因 子は完全行列法によって精密化し，最終信頼度因子 $R$ は 0.084 $\left(R_{\mathrm{w}}\right.$ 0.097) であった。解析は, SDP/VAX (Enraf-Nonius \& B. A. Frenz \& Associates, Inc.) によって行った。

\title{
Special Articles on \\ New Aspects of Silicon Chemistry
}

\section{Photoreactions of Cyclotetrasilane and Cyclotetragermane in the Presence of Azobenzenes}

\author{
Akihito Sakakibara, Takeshi Tsumuraya, Yoshio $\mathrm{K}_{\mathrm{AbE}}$ \\ and Wataru AnDo* \\ Department of Chemistry, The University of Tsukuba; Tsukuba-shi 305 Japan
}

Photoreactions of octaphenylcyclotetrasilane and azobenzenes give 1-(1,2-diarylhydrazo)$1,2,2,3,3,4,4$-heptaphenyl-1, 2,3,4-tetrasila-1, 2, 3, 4-tetrahydronaphthalenes [1] and [2] in good yields which were identified by NMR spectra and/or X-ray crystal analysis.

In the reaction of azobenzene with octaphenylcyclotetragermane, 1, 2, 3, 3, 4, 4, 5, 5, 6, 6decaphenyl-1,2-diaza-3, 4, 5, 6-tetragermacyclohexane [ 3$]$ is obtained. 